\title{
Assessing stack ventilation strategies in the continental climate of Beijing using CFD simulations
}

Article

Accepted Version

Essah, E. A., Yao, R. and Short, A. (2017) Assessing stack ventilation strategies in the continental climate of Beijing using CFD simulations. International Journal of Ventilation, 16 (1). pp. 61-80. ISSN 1473-3315 doi:

https://doi.org/10.1080/14733315.2016.1203609 Available at https://centaur.reading.ac.uk/66627/

It is advisable to refer to the publisher's version if you intend to cite from the work. See Guidance on citing.

Published version at: http://www.tandfonline.com/action/journallnformation? show=aimsScope\&journalCode=TJOV20\#.VE9Insnlfps

To link to this article DOI: http://dx.doi.org/10.1080/14733315.2016.1203609

Publisher: Taylor \& Francis

All outputs in CentAUR are protected by Intellectual Property Rights law, including copyright law. Copyright and IPR is retained by the creators or other copyright holders. Terms and conditions for use of this material are defined in the End User Agreement. 


\section{CentAUR}

Central Archive at the University of Reading

Reading's research outputs online 


\title{
Assessing stack ventilation strategies in the continental climate of Beijing using CFD simulations
}

\author{
Emmanuel A Essah ${ }^{\mathrm{a}, \mathrm{b}}$, Runming Yao ${ }^{\mathrm{b}}$, Alan Short ${ }^{\mathrm{c}}$ \\ ${ }^{a}$ Key Laboratory of the Three Gorges Reservoir Region's Eco-Environment, Ministry of Education, Chongqing \\ University, China \\ ${ }^{b}$ School of Construction Management and Engineering, University of Reading, Whiteknights, PO Box 219, Reading \\ RG6 6AW, UK \\ ${ }^{c}$ Department of Architecture, University of Cambridge, 1-5 Scroope Terrace, Cambridge CB21PX,UK
}

\begin{abstract}
The performance of a stack ventilated building compared with two other building designs have been predicted numerically for ventilation and thermal comfort effects in a typical climate of Beijing, China. The buildings were configured based on natural ventilation. Using actual building sizes, Computational Fluid Dynamics (CFD) models were developed, simulated and analysed in Fluent, an ANSYS platform. This paper describes the general design consideration that has been incorporated, the ventilation strategies and the variation in meshing and boundary conditions. The predicted results show that the ventilation flow rates are important parameters to ensure fresh air supply. A Predicted Mean Vote (PMV) model based on ISO-7730 (2005) and the Predicted Percentage Dissatisfied (PPD) indices were simulated using Custom Field Functions (CFF) in the fluent design interface for transition seasons of Beijing. The results showed that the values of PMV are not within the standard acceptable range defined by ISO-7730.
\end{abstract}

Keywords: Stack ventilated buildings, PMV, PPD, CFD, Natural Ventilation

\section{Nomenclature}

$\begin{array}{ll}\boldsymbol{N} \boldsymbol{V} & \text { natural ventilation } \\ \boldsymbol{A} \boldsymbol{G T} & \text { advance glass technological } \\ \boldsymbol{S V B} & \text { stack ventilated building } \\ \boldsymbol{P P D} & \text { Predicted Percentage Dissatisfied } \\ \boldsymbol{P M V} & \text { Predicted Mean Vote } \\ \boldsymbol{C F D} & \text { Computational Fluid Dynamics } \\ \boldsymbol{C F F} & \text { Custom Field Functions } \\ \boldsymbol{A} & \text { area of the opening }\left(\mathrm{m}^{2}\right) \\ \boldsymbol{\Delta} \boldsymbol{p} & \text { stack pressure }(\mathrm{Pa}) \\ \boldsymbol{\rho} \boldsymbol{i} & \text { density of internal air }\left(\mathrm{kg} / \mathrm{m}^{3}\right) \\ \boldsymbol{g} & \text { acceleration due to gravity }\left(\mathrm{m} / \mathrm{s}^{2}\right) \\ \boldsymbol{h} & \text { height of the stack }(\mathrm{m}) \\ \boldsymbol{\dot { m }} & \text { mass flow rate of air }(\mathrm{kg} / \mathrm{s})\end{array}$

$\boldsymbol{M}$ metabolic rate $\left(\mathrm{Wm}^{-2}\right)$

$\boldsymbol{W}$ effective mechanical power $\left(\mathrm{Wm}^{-2}\right)$

$\boldsymbol{I}_{\boldsymbol{c l}}$ clothing insulation $\left(\mathrm{m}^{2} \mathrm{~K} / \mathrm{W}\right)$

$f_{c l} \quad$ clothing surface area factor

$\boldsymbol{t}_{\boldsymbol{a}}$ air temperature $\left({ }^{\circ} \mathrm{C}\right)$

$\boldsymbol{t}_{\boldsymbol{c l}} \quad$ Clothing surface temperature $\left({ }^{\circ} \mathrm{C}\right)$

var relative air velocity $(\mathrm{m} / \mathrm{s})$

$\boldsymbol{T}_{\boldsymbol{i}} \quad$ internal air temperature (K)

$\boldsymbol{T}_{\boldsymbol{e}}$ external air temperature (K)

$\boldsymbol{h}_{\boldsymbol{c}}$ Convective heat transfer coefficient $\left(\mathrm{W} / \mathrm{m}^{2} . \mathrm{K}\right)$

$\boldsymbol{C}_{\boldsymbol{d}}$ discharge coefficient for the openings (-minus)

$\boldsymbol{P}_{\boldsymbol{a}}$ Water vapour partial pressure $\left(\mathrm{P}_{\mathrm{a}}\right)$

$\overline{t_{r}} \quad$ mean radiant temperature $\left({ }^{\circ} \mathrm{C}\right)$ 


\section{Introduction}

Ventilation plays an essential role in securing good indoor air quality, health, wellbeing and thermal comfort (Liddament 1996). Natural ventilation is often considered as the most efficient design strategy and a healthy solution in low energy building designs (Yao et al. 2009). In addition, Zhai et al. (2011) maintains that natural ventilation is a traditional, cost effective technique to cool and ventilate buildings while Ji et al. (2009) states that natural ventilation has the potential for reducing building energy consumption and also offering an improved indoor environment compared to conventional mechanical ventilation and air conditioned systems. However, the implementation of natural ventilation (NV) can be constrained by many factors that include local climatic conditions and that of the microclimates such as temperature and wind velocities that are around buildings.

In a study by Yao et al. (2009) they note that a single natural ventilation system will not be sufficient to achieve the required standards of thermal comfort in continental climate conditions that are noted for their warm and humid conditions. In such conditions the use of mixed-mode or hybrid ventilation as a response to the needs for indoor comfort and energy efficiency offers a compromise. In another design where stack ventilation is considered, the advantage of $\mathrm{NV}$ and stack ventilated buildings (SVB) is the utilisation of the effect of wind pressure, air movement and, buoyancy forces generated from internal and external heat changes and (Yao et al. 2009). These mechanisms ensure that the building can operate at the desired comfort level during extreme climate conditions (Zhai et al. 2011). With these design factors in place, the use of fans is ideally not required. This therefore makes hybrid ventilation applicable to a wide range of climatic and environmental changes. However, it also faces challenges that include weather conditions, microclimates, and building design of the locality.

Ji et al. (2009) identifies two of such challenges as features that determine the performance of a passive system that maximises the systems period of operation. To address such challenges computer simulations tools have been recommended (Kennett 2001) to visualise the variation in changing parameters. Over the years, these tools have been developed to provide acceptable predictions of relevant features that influence building design and its functional optimisations (i.e. including the thermal performance of buildings) (Zhai et al. 2011). Computational Fluid Dynamics (CFD) and Dynamic Thermal Simulation (DTS) are two of such computer simulation tools that have been widely used for building performance predictions (Ji et al. 2009). Significantly, the impact of variables such as humidity, inlet and outlet opening positions, can also be investigated using these tools (Abanto et al. 2004). Kim and Hwang (2009) argue that prior to real application to purpose build, it is vital for the performance of hybrid ventilation systems to be predicted using the CFD or similar modelling tools. Notably, gathering information about air flow patterns in buildings is one of the key measures to understand the significance of integrating advanced ventilation strategies into building designs. In most instances, the main parameters investigated include; air velocity, temperature, and relative humidity. All these parameters are important when assessing the indoor air quality (IAQ) and thermal comfort of the building (Abanto et al. 2004).

This paper presents investigations from an advanced ventilation system using CFD simulations to assess the effect of air movement within an environment and through an exhaust from a stack integrated building, with a design setting in Beijing. In this paper analysis is performed for three building design (referred to as modes) over a transition period (season). A comprehensive study and analysis framework based on CFD models and BS EN ISO 7730 (2005) has been developed to investigate the thermal comfort conditions of each design. The components of the framework consist of the air movement, temperatures, predicted mean vote (PMV), predicted percentage dissatisfied (PPD) and transport phenomena (humidity and carbon dioxide concentrations).

\section{Climate of Beijing}

The climate of China is extremely diverse and variable with a tropical climate in the south and a sub-arctic climate in the north (Yao et al. 2009). In Yao et al.'s (2009) research five cities including Beijing were selected to represent the five climatic zones according to the "Thermal Design Code" for buildings in China. Beijing is subject to the Siberian air masses that move southward across the Mongolian Plateau, winters are cold and dry. Summers are hot, driven by warm and humid monsoon winds from the southeast (Yao et al. 2009; Short et al. 2012). In this study weather obtained from the Chinese National Weather Data, which is for the purpose of understanding the indoor environment design of buildings (China Standard Weather Data for Building Thermal Environment Design (CSWD) 
,CSWD 2005). The CSWD has generated typical meteorological data for years (TMY) based on hourly data collected between 1971 and 2003. The key external design data as in Figure 1, represents annual hourly external Dry-Bulb Temperature and humidity in Beijing (CSWD 2005).

\section{Building Design and Relevance}

In this study, three distinct building designs; one existing, the other designed to investigate advanced glazing technology (AGT) and finally a design that integrates eight stack ventilation systems have been considered and modelled for the climate of Beijing. These distinct design features impact significantly on their respective indoor air flow patterns. As Beijing continues to become a modern yet more populated city, people are continually faced with increasing choices of when they want to purchase or rent commercial buildings. Besides the prices of these buildings and location, as hinted by $\mathrm{Li}$ and $\mathrm{Li}$ (2013), the indoor air quality which is influenced by environment is a major determinant for those who would eventually own the place and/ or work in the building. In addition, according to Chen (2007), generally buildings in Beijing, must to be designed to ensure that the building layouts permit free and easy flow of ventilation within all zones. The relevance of this research is further enhanced as eluded by Chen (2007), in that the outcome from the study suggests that mechanical or stack ventilation might be needed in order enhance ventilation in buildings in Beijing.
The Internal specifications of the models for the purpose of the CFD simulation were simplified using AutoCAD and Solidworks. However; the external features of the three buildings was kept unchanged. The design of the advance glass technological (AGT-Figure 3 ) was based on the current building strategy (Figure 2). Equally, the stack ventilated model (Figure 4) combines the current building design and eight stack ventilation systems to optimise the NV strategy. Detailed design implications of the NV system were investigated for the SVB. Details of the three design modes are illustrated in Table 1.

The first two designs (hereafter referred to as cases) were simulated for comparison, analyses and interventions. The simulated attributes from the two modes were then implemented into the third mode.

\subsection{Design Strategies: As-built and AGT Models}

Case 1, (Figure 3) is a building that was designed using the Historical Performance Standards in the 1980's and current building regulations of China. The design strategy in Case 2 is an 'active strategy' that explores the effectiveness of the advanced glazing technology. The initial design was developed to maximise the use of day lighting and solar gain in winter. Therefore, the south facing façade was fully glazed with an area dedicated for the integration of Photovoltaic (PV) system installation (not illustrated in this paper). In addition, the east and west façades were also approximately $50 \%$ glazed.

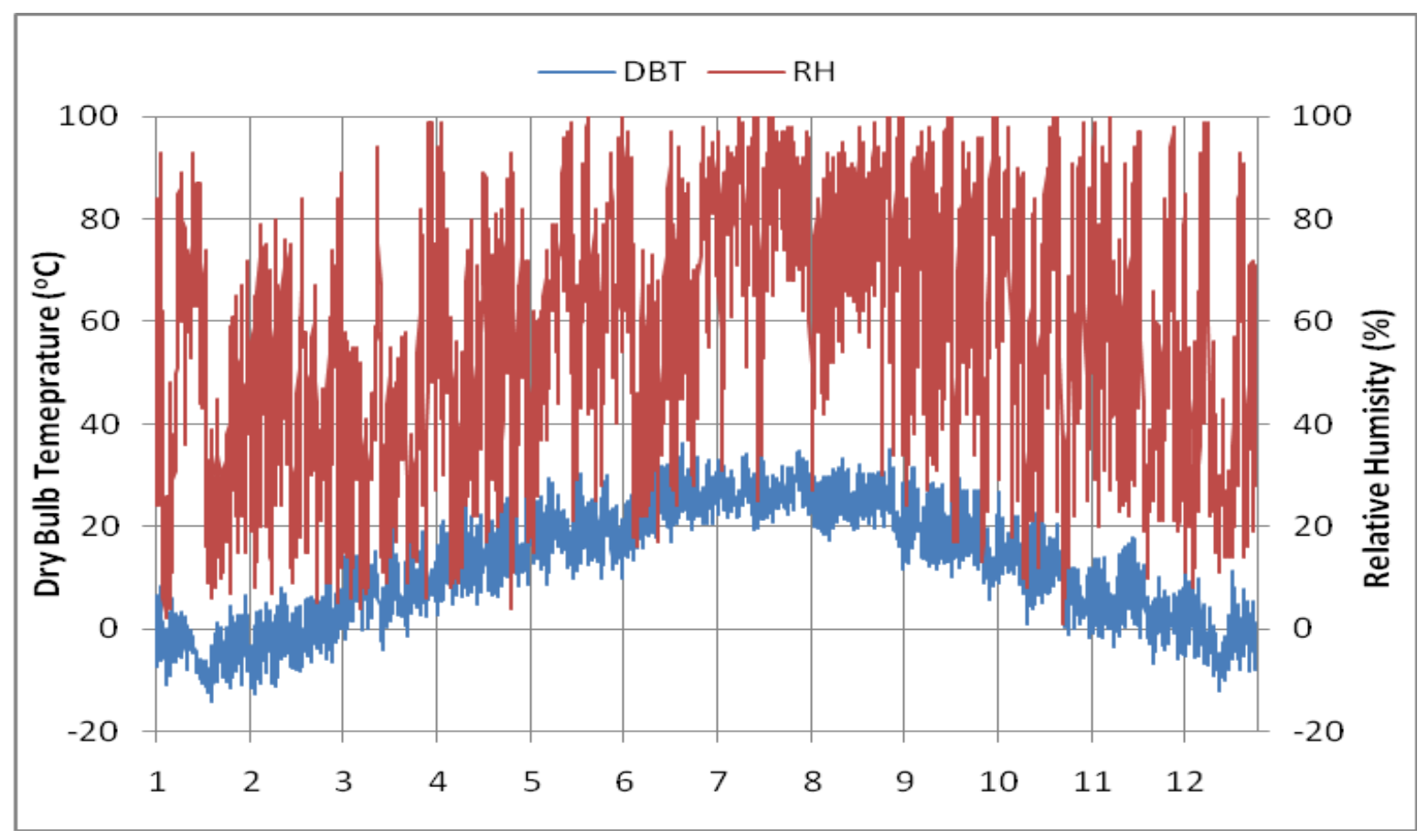

Figure 1. Hourly outdoor Dry-Bulb temperature and relative humidity in Beijing (CSWD 2005) 
Table 1. Characteristics of the three building design modes

\begin{tabular}{|l|l|l|l|}
\hline Design & Description & Floor Area $\left(\mathbf{m}^{\mathbf{2}}\right)$ & Floor Volume $\left.\mathbf{( m}^{\mathbf{3}}\right)$ \\
\hline Case 1 & As-built with NV & 4200 & 9009 \\
\hline Case 2 & NV of the AGT & 4200 & 10,386 \\
\hline Case 3 & NV with 8 stack effects & 4112 & 10,448 \\
\hline
\end{tabular}

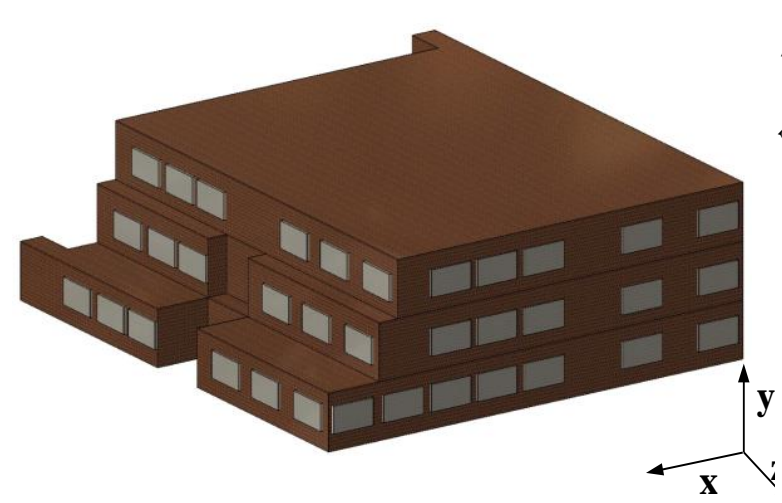

Figure 2. As-built model (for 1980s \& Current)

For the purpose of this study, the façade of the buildings were considered without any additional interventions. This was adapted to simplify the model, effectively reducing the simulation time. The designs presented were developed to investigate the airflow regime and other parameters cited in section 1. Short et al. (2012) discuss further details of the building designs, hence not discussed in this text.

\subsection{Case 3: Building design with 8 stacks}

This design mode draws on the integration of 8 ventilation stacks within an existing building design. Figure 4 shows the CAD model of the proposed design that incorporates NV. This design comprises 4 storeys; a basement and 3 other floors. The building is designed to utilise the stack effect in which warm air which has lower density than cold air rises and exchanged by fresh cold air (higher density) due to buoyancy of air (Lomas 2007). As warm air escapes from the top (exhaust path- Figure 5 ), it creates reduced pressure in the building drawing colder air into the building from the outside (Figure 5). This design was adapted as an improvement on Case 1 and 2 which was observed to require mechanical ventilation to support the required air change rates (Short et al. 2012). As with the AGT, there is the integration of a PV system in the building design which is not incorporated in the CFD modelling interface- Figure 4).

Figure 5 illustrates the cross-section of the proposed building layout and the flow patterns envisaged.
Significantly, a suitable design of the building would ensure constant flow of air at all times through the building and the stack. Where temperature variations around the building are considered, the higher the temperature difference between the top of the stack and the outside air, the more effective the stack (Jankovic 2012).

The implementation of stack effect in buildings causes air infiltration from a ground level entrance at the very minimum (Figure 5) since most buildings are not totally sealed. Typically in climates such as that of study, during the heating season, the warmer indoor air rises up through the building and escapes at the top either through open windows, ventilation openings, exhaust or other forms of leakage. The rising warm air reduces the pressure at the base of the building, drawing cold air through openings and leakage. During the cooling season, the stack effect is reversed, but is typically weaker due to lower temperature differences.

In this design case, there is a pressure difference between the outside air and the air inside the building caused by the difference in temperature between the outside air and the inside air. This pressure difference $(\boldsymbol{\Delta P})$ is the driving force for the stack effect. Considering a simple (low level inlet supply) stack driven displacement ventilation, the equation that governs the driven pressure of the overall stack effect of the building and the resultant air flow regime is

$$
\Delta p=\rho_{i} g h\left(\left(T_{i}-T_{e}\right) / T_{e}\right)
$$


As with this design, Equation 1 applies because of flow of air inside and outside the building. For multi-floors, $\boldsymbol{h}$ is the height of the stack (m).

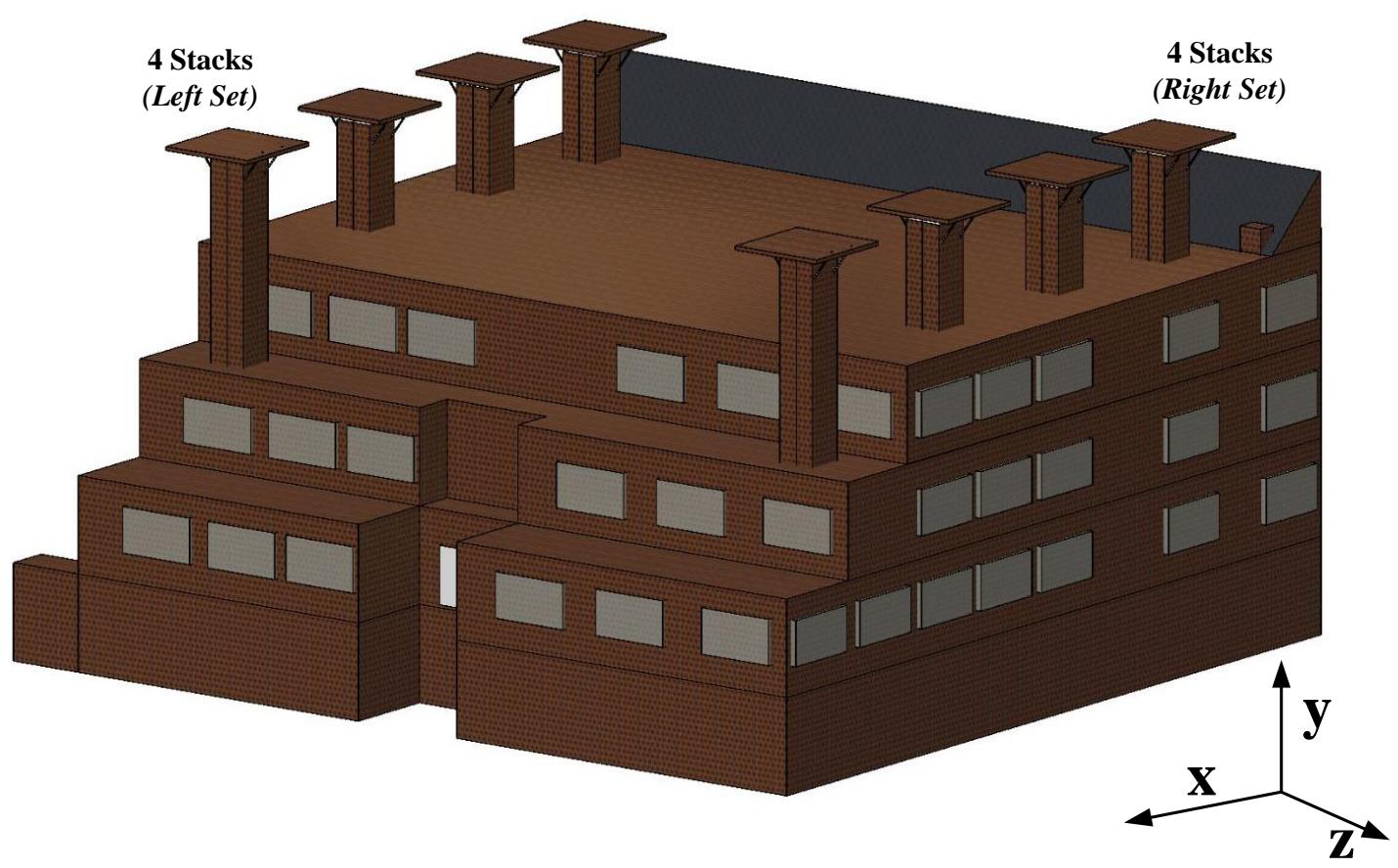

Figure 4. Design of Case 3 with 8 Stacks

(13) (22)

(23) (16) (15) (28)

(27)

(17)

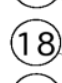

(25)

24

(26)

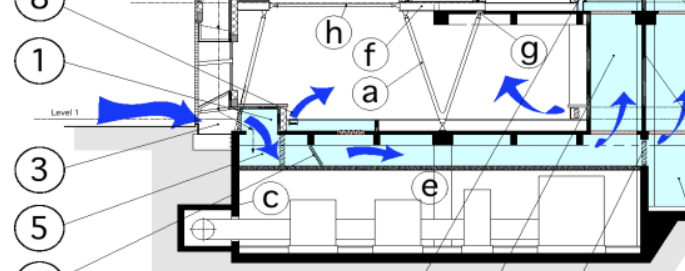

(6)

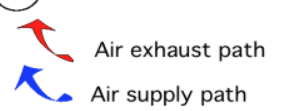

(11) 9

(7)

(4) (10) (12)

(4) (5)

(3) (2)

$\square$ New holes to be formed in concrete

Figure 5. North-south cross section: existing concrete frame shown in solid black 
Key

1. Low level air intake to south

2. Air intake to north

3. Louvre blades

4. Fresh air collection chamber to feed plenum

5. Dampers

6. Heating elements

7. Damper connecting north and south sections of plenum to balance pressures

8. Floor register supplying air

9. Fresh air fountain rising to level 2

10. Internal divisions within fresh air fountains

11. Air outlet to level 2

12. Internal divisions within fresh air fountains

13. Ventilation exhaust stack

14. Full height atrium to north

15.Dampers connecting levels 2 and 3 to south exhaust stacks

For a typical indoor environment, the air density varies with temperature as well as the humidity ratio $\left(W_{a}\right)$. Equation 2 illustrates the relation between the internal air temperature and humidity ratio in terms of the ambient (external) conditions (ASHRAE Fundamentals, 2009).

$T_{i}=32.6+0.066 T_{e}+32 W_{a}$

The humidity ratio, which is defined as the ratio of the mass of water vapour in an air parcel to the mass of dry air for the same parcel, can also be expressed in terms of total or barometric pressure $\left(P_{t}\right)$ and the external water vapour pressure $\left(P_{a}\right)$ as illustrated in Equation 3.

$W_{a}=0.622 p_{a} /\left(p_{t}-p_{a}\right)$

Where

$\bullet$

$m$ mass flow rate of air $(\mathrm{kg} / \mathrm{s})$

$\Delta \boldsymbol{p}$ stack pressure, i.e. pressure difference between inside and outside air $(\mathrm{Pa})$

$\boldsymbol{\rho}_{\boldsymbol{i}} \quad$ density of internal air $\left(\mathrm{kg} / \mathrm{m}^{3}\right)$

g acceleration due to gravity $\left(\mathrm{m} / \mathrm{s}^{2}\right)$

$\boldsymbol{h}$ height of the stack $(\mathrm{m})$

$\mathrm{Ti}$ internal air temperature $(K)$

Te external air temperature $(K)$

$\boldsymbol{A}$ area of the opening ( $\mathrm{m} 2)$

$\boldsymbol{C d}$ discharge coefficient for the openings (-minus)
16. Exhaust stack

17. Dampers

18. Open grille access platform

19. Return air

20. Level 1 exhaust directly into atrium

21. Levels 2 and 3 compartmented, opening vents exhaust into atrium

22.Fans at stack terminations engage when natural ventilation flows stall to prevent downdraught

23 Photovoltaic panels installed on stack tops

24. Stacks shade north lights

25 Brick masonry screens shade roof glazing

26. Louvre admits exhaust air from level 1 to stack

27.Photovoltaic panels on south-facing atrium roof

\section{Numerical Modelling and Simulation}

Over the years there has been growing interest in the development of CFD codes to improve building design. This more so because experimental studies and analysis of buildings is time consuming, expensive, require sophisticated sensors and instrumentation techniques (Gaspar et al. 2003; Blocken et al. 2005; Essah 2009). In recent years, CFD have been widely used as a method of simulating room airflow, studying indoor environment issues and to produce data that may be otherwise difficult to obtain through in situ measurements (Mahyuddin et al., 2014). Modelling is one option currently available to determine and predict air movement in buildings. CFD modelling has the advantage of being less time consuming and less expensive (Chow 1996) in relation to purpose built systems for monitoring. However, in most cases this has been limited to simplified systems. This is because in any given volume of a building, airflows are characterised as being non-isothermal, turbulent, three dimensional and non-steady (Essah 2009; Loomans 1998).

In this paper the actual sizes of the case buildings have been considered to ensure a generic understanding of the actual conditions that is expected. All Cases were designed with the inclusion of all the air distribution routes; around partitions, lift shafts, stacks etc (illustrations in figure 5). These were incorporated to ensure a more realistic design of the modelled buildings. Using details from an existing building (Case 1), predicted conditions in the other Cases were compared. The CFD tool Ansys Fluent 14 was used to simulate the buildings to investigate the air movement, temperature, thermal comfort and $\mathrm{CO}_{2}$ stratification. A steady state flow regime was assumed for the purpose of this study. 


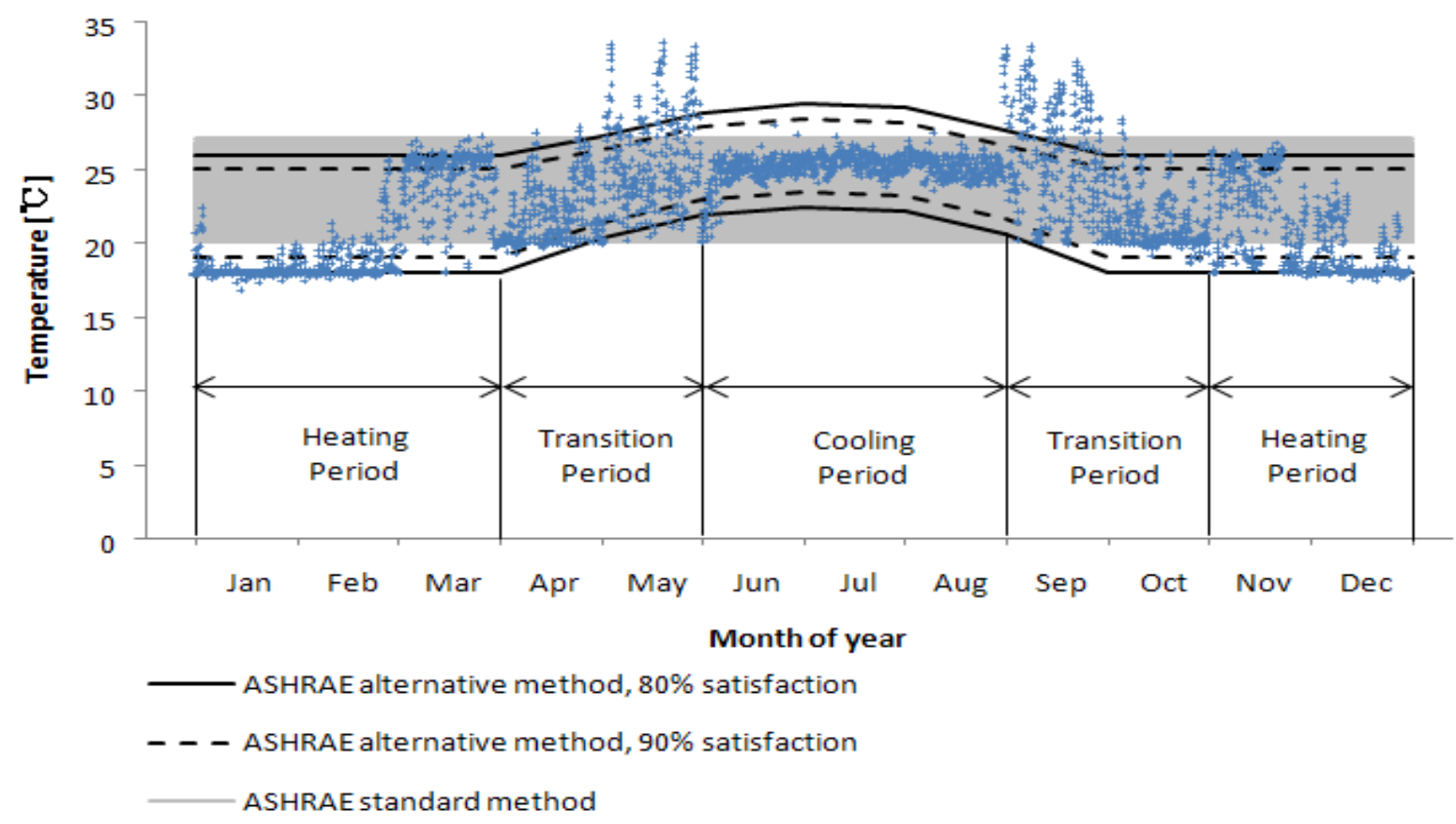

Figure 6. Performance of design Cases 1 to 3 set against ASHRAE standards (source Short et al. 2012)

\subsection{Control strategies}

Three control strategies as outlined within ASHRAE standards and illustrated in Figure 6 were considered as boundary conditions in the CFD simulations. However because of the functionality of the stack system only the third strategy was implemented in this study.

1. As stipulated in the Chinese regulation (CSWD 2005) the heating period includes January, February, March, November and December. The ventilation system only provides fresh air according to the health requirement (i.e.30 $\mathrm{m}^{3} / \mathrm{h}$.person) during this period. This period is noted to be Hot and/or humid.

Note that during the heating period, the capacity for natural stack ventilation is closed off.

2. Although heating is an important issue in Beijing, they also require cooling. The Cooling period is from June through to August. In this period, the 8 stack ventilation system will operate as a mixed-model control strategy.

3. In Beijing, the period of comfort has been marked to be within a transition period. The Transition period is over two levels. The first period is April and May and the second period is from September to October. During this period, no space heating and air-conditioning systems are in operation. It is envisaged that the stack ventilation system will operate on the basis of maintaining indoor air temperature not to exceed the upper limit of the adaptive thermal comfort temperatures. Stack ventilation would operate during the night when necessary. The effect of the stack during the transition period (Figure 6) remains un-investigated.

\subsection{Modelling Design Strategies}

In the design phase the geometry of the buildings were all considered to be fluid to reduce any design constraints that may be encountered due to the wall interface. The design of Cases 2 and 3 is driven by the desire to achieve energy efficiency and to meet the operational functionality of the buildings. In the design of the facades (that is to predict and maximise the uptake of NV systems for adequate ventilation rates and indoor air quality), U-values of the materials are considered for heat transfer simulations. This is introduced during the pre-processing phase through the materials panel which provides input for conductivity values of each material used. Also, the thickness of the material was specified in the boundary condition panel of the surface (in this case specified). In the context of this study, the resistance of a building material is derived by the following formula:

$$
R=(1 / k) * d
$$

Where $\boldsymbol{k}$ is the conductivity of the building material and $\boldsymbol{d}$ is the material thickness.

The formula for the calculation of a $\mathrm{U}$ value is

$U=1 /\left(R_{S O}+R_{S i}+R_{1}+R_{2} \ldots R_{n}\right)$ 
Where $\boldsymbol{R}_{\boldsymbol{s} \boldsymbol{o}}$ is the fixed external resistance, $\boldsymbol{R}_{\boldsymbol{s} i}$ is the fixed internal resistance and $\boldsymbol{R}_{\boldsymbol{I}} \ldots \boldsymbol{R}_{\boldsymbol{n}}$ is the sum of all the resistances of the building materials in the constructional element. So from the above formula inputs for $\boldsymbol{k}$ and $\boldsymbol{d}$. are provided.

In addition, the impact of surface radiation were also accounted for. This was introduced into the boundary conditions as heat flux. It must be noted that, the pressure values in all 3 design Cases are much lower than what would be expected in a building that uses mechanical systems. As discussed by Short and Lomas (2007), to deliver a known volume of air, the air supply and exhaust routes must be designed with lower resistances than in a mechanical system.

Therefore, to investigate these design concepts, two transition periods (Figure 6) were considered and categorised as follows;

- Transition Season A: This represents periods identified in Figure 6 that includes April to May.

- Transition Season B: similarly, this represents months from September to October

\subsection{CFD Design and Boundary Conditions}

The geometry of the models always dictates the grid requirements. Considering all three models, the more complex the geometry the more detailed the grid. As an input, the sources of external air supply into the building were very small compared to the total size of the building (i.e. typical for all three modes), but of high significance. Representative wind speeds, obtained from meteorological data were assigned as velocity inlets on the external façade.
Pressure inlet and outlet values (along the stack) allowing the movement of air in and out of the building structure were imposed as boundary conditions. Additional boundary conditions are summarised in Table 2.

Based on the characteristics and comparison of three $k-\varepsilon$ turbulence models (standard, realizable and RNGRe-Normalisation Group) extensively discussed by Essah (2009), the low Reynolds number realizable $k-\varepsilon$ turbulence model was chosen as the main solver in this study. To reduce the complexities in the structural design within the CFD model and the number of meshing elements for Case 3, all 8 stacks (Figure 7a) were simplified by excluding their canopies (Figure $7 b)$.

With regards to the radiation effect, all walls are considered diffuse except for the windows. A default internal emissivity of the walls was set to be 0.8 . The turbulent intensity at all inlets and outlets was $1 \%$.

\section{Meshing}

Prediction of airflows is based on a solution of fundamental flow equations, however it is not possible to solve these differential equations directly for the flow regime of a zone/volume hence a numerical method is required (Nielsen et al. 2007). The building designs in this research impacted significantly on the meshing process. Meshing required the modelled zone to be divided into grid points. The differential equations for the numerical methods were then transformed into discretization equations formulated around each grid point. To reduce turbulence modelling errors at the near wall region, 30 cells were uniformly distributed to all surfaces for the inner $0.02 \mathrm{~m}$. Though Nielsen et al. (2007) consider this as a "rule of thumb", Essah (2009) argues that, turbulence modelling errors could be further reduced with more cells over the stipulated length (i.e. $>30$ cells per $0.02 \mathrm{~m}$ ).

Table 2. Boundary conditions imposed on all 3 Cases

\begin{tabular}{|l|l|l|l|l|l|}
\hline & Parameters & Transition Season A & \multicolumn{2}{l|}{ Transition Season B } \\
\hline & & Scenario 1 & Scenario 2 & Scenario 1 & Scenario 2 \\
\hline \multirow{3}{*}{ EXTERNAL } & Temperature $\left({ }^{\circ} \mathrm{C}\right)$ & 23.8 & 11 & 23.8 & 9.2 \\
\cline { 2 - 6 } & Wind Speed $\left(\mathrm{ms}^{-1}\right)$ & 2.3 & 4 & 1.58 & 3.3 \\
\cline { 2 - 6 } & $\mathrm{RH}(\%)$ & 61 & 85.5 & 75 & 97.5 \\
\cline { 2 - 6 } & $\begin{array}{l}\mathrm{CO}_{2}(400 \mathrm{ppm})-\text { mass } \\
\text { fraction }\end{array}$ & 0.001 & 0.001 & 0.001 & 0.001 \\
\hline INTERNAL & Radiator Temperature $\left({ }^{\circ} \mathrm{C}\right)$ & N/A & 19 & N/A & 19 \\
\cline { 2 - 6 } & $\begin{array}{l}\mathrm{CO}_{2}(\sim 100 \text { people)-mass } \\
\text { fraction }\end{array}$ & 0.1 & 0.1 & 0.1 & 0.1 \\
\hline
\end{tabular}



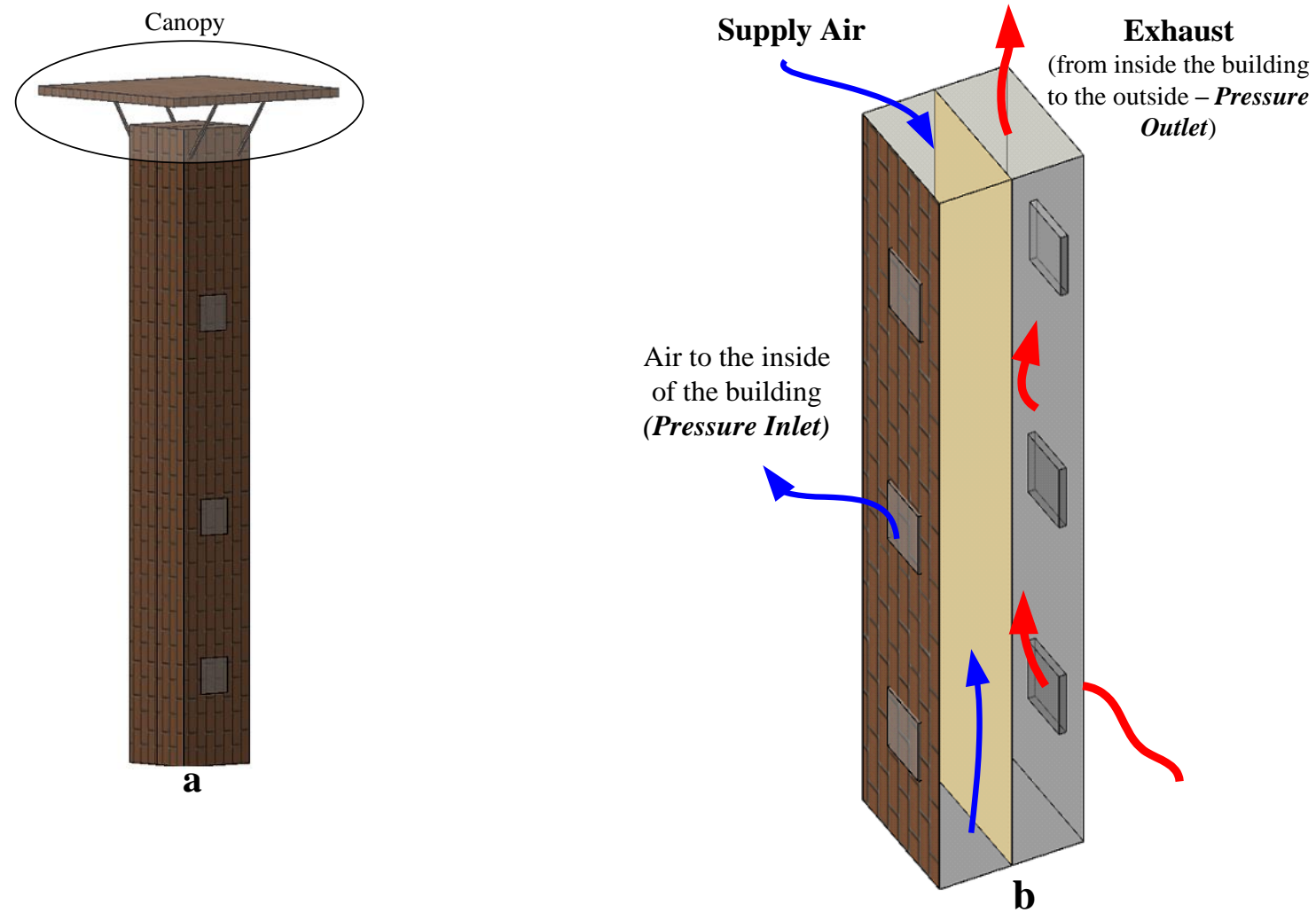

Figure 7. A complete stack-as built (a) and a cross-section of the CFD design stack (b) with boundary conditions imposed on surfaces

Table 3. A summary of meshing characteristics of the 3 models

\begin{tabular}{|l|l|l|l|l|l|l|l|}
\hline $\begin{array}{l}\text { Parameters } \\
\text { Design } \\
\text { Model }\end{array}$ & $\begin{array}{l}\text { Size } \\
(\mathrm{mm})\end{array}$ & $\begin{array}{l}\text { Element } \\
\text { Quality }\end{array}$ & Smoothing & $\begin{array}{l}\text { Aspect } \\
\text { Ratio }\end{array}$ & Skewness & $\begin{array}{l}\text { No. of } \\
\text { Elements }\end{array}$ & Type(method) \\
\hline Case 1 & 300 & Fine & High & 10.3 & 0.91907 & $4,219,970$ & $\begin{array}{l}\text { Tetrahedron } \\
\text { (adaptive) }\end{array}$ \\
\hline Case 2 & 200 & Fine & Medium & 17.6 & 0.94969 & $9,526,354$ & $\begin{array}{l}\text { Tetrahedron }+ \\
\text { Hex Dominant }\end{array}$ \\
\hline Case 3 & 230 & Fine & High & 32.2 & 0.96622 & $10,191,839$ & $\begin{array}{l}\text { Tetrahedron } \\
\text { (adaptive) }\end{array}$ \\
\hline
\end{tabular}

This is because of how sensitive and/or small the meshing area is, in relation to the rest of the zone. In addition, the design of the model may require a multi-block grid (i.e. dividing the zone into smaller volumes-blocks) approach to optimise the meshing grid.

In this research fine grids were used in areas with large gradient to minimise false diffusion and dispersive errors. An adaptive grid was modified according to the distribution of the variables in the solution domain. One significant parameter of meshing is the $y^{+}$-value. The $y^{+}$-value as discussed by Awbi (1998) obtained for all three models was within the same output range. Three significant regions were identified in relation to the $y^{+}$-values of the models. The viscous sublayer close to the wall region was given by $y^{+}<10$. The inner region (turbulent region) is between $10<y^{+}<150$ and the outer region is given by $y^{+}>150$. It must be noted that different mesh sizes were used to establish grid-independency of the results. There were several permutations to ensure that the mesh and other parameters were suitable for simulation. The final functional parameters that were obtained for each model are summarised in Table 3. 
In design Case 3, the aspect ratio was relatively high but within the limit of functionality in comparison with the other models. This is due to the complexity in the design. To reduce this further, the element size would increase, increasing the simulation time.

Generically, the attributes associated with mesh quality are: the node point distributions, smoothness and skewness (i.e. the difference between the shape of the cell and the shape of an equilateral cell of equivalent volume). Highly skewed cells which can occur with different mesh types when volumes are merged can decrease the accuracy and destabilize the solution (Essah 2009). Significantly, as presented in Table 3, the skewness values were below the maximum required value of 0.98. Any value more than this decreases the accuracy of the results. The number of elements is also within the limits for simulation.

\section{CFD input of PMV and PPD indices}

The thermal comfort of occupants in the buildings were predicted by calculating the Predicted Mean Vote (PMV) developed by Fanger (1972) and given in BS EN ISO 7730 (2005).
Fanger's algorithm (BS EN ISO 7730, 2005), is used to determine the combinations of the indoor space environment and personal factors within the buildings to produce the required thermal conditions suitable for $80 \%$ or more of the occupants in the zone or building. This empirical data takes into account six variables, four of which relate to the working environment (air temperature, mean radiant temperature, air velocity and relative humidity of the air), while the other two (clothing insulation and the metabolic rate) refer to individual variables of occupants. Equations 6-9 follow an iterative process to determine the PMV values using written functions incorporated as codes in the fluent interface. This was essential because the fluent interface does not include built-in functions for thermal comfort simulations within a zone or a building. These parameters were introduced within the Custom Field Function $(C F F)$ in the pre-processing stage.

$$
P M V=\left(0.303 e^{-0.036 M}+0.028\right) \times\left\{\begin{array}{l}
(M-W)-3.05 \times 10^{-3} \times\left[5733-6.99(M-W)-P_{a}\right]-0.42 \times[(M-W)-58.15] \\
-1.7 \times 10^{-5} M\left(5867-P_{a}\right)-0.0014 M\left(34-t_{a}\right)-3.96 \times 10^{-8} f_{c l} \times\left[\left(t_{c l}+273\right)^{4}-\left(\overline{t_{r}}+273\right)^{4}\right] \\
-f_{c l} h_{c}\left(t_{c l}-t_{a}\right)
\end{array}\right\}
$$

where

$$
\begin{aligned}
& t_{c l}=35.7-0.028(M-W)-I_{c l}\left\{3.96 \times 10^{-8} f_{c l} \times\left(\left(t_{c l}+273\right)^{4}-\left(\overline{t_{r}}+273\right)^{4}\right]+f_{c l} h_{c}\left(t_{c l}-t_{a}\right)\right\} \\
& h_{c}=\left\{\begin{array}{ll}
2.38\left(t_{c l}-t_{a}\right)^{0.25} & \text { for } 2.38\left(t_{c l}-t_{a}\right)^{0.25}>12.1 \sqrt{v_{a r}} \\
12.1 \sqrt{v_{a r}} & \text { for } 2.38\left(t_{c l}-t_{a}\right)^{0.25}<12.1 \sqrt{v_{a r}}
\end{array}\right\}
\end{aligned}
$$

$$
\begin{aligned}
& \text { M metabolic rate }\left(\mathrm{Wm}^{-2}\right) \\
& \boldsymbol{W} \text { effective mechanical power }\left(\mathrm{Wm}^{-2}\right) \quad \text { var } \quad \text { relative air velocity }(\mathrm{m} / \mathrm{s})
\end{aligned}
$$

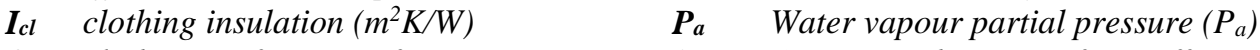

$$
\begin{aligned}
& \boldsymbol{f}_{c l} \quad \text { clothing surface area factor } \quad \boldsymbol{h}_{c} \quad \text { Convective heat transfer coefficient }\left(\mathrm{W} / \mathrm{m}^{2} . K\right. \\
& \boldsymbol{t}_{\boldsymbol{a}} \text { air temperature }\left({ }^{\circ} \mathrm{C}\right) \quad \overline{t_{r}} \quad \text { mean radiant temperature }\left({ }^{\circ} \mathrm{C}\right) \\
& f_{c l}=\left\{\begin{array}{ll}
1.00+1.290 l_{c l} & \text { for } I_{c l} \leq 0.078 m^{2} K / W \\
1.05+0.645 l_{c l} & \text { for } I_{c l}>0.078 m^{2} K / W
\end{array}\right\} \\
& P P D=100-95 \times \exp \left(-0.03353 \times P M V^{4}-0.2179 \times P M V^{2}\right)
\end{aligned}
$$


Once $t_{r}, h_{c}, f_{c l}$ and $t_{c l}$ had been estimated, the PMV was computed as an additional function in the fluent user-defined interface. Knowing the PMV value, the percentage of dissatisfaction (PPD) index was determined. This is also integrated into the CFF interface using Equation 10 as defined in BS EN ISO 7730 (2005).

All simulation and analyses were carried out for constant values of relative humidity $\mathrm{RH}=50 \%$, metabolic rate $\mathrm{M}=70 \mathrm{~W} / \mathrm{m}^{2}(\mathrm{M}=1.2 \mathrm{Met})$ and clothing level $(0.5 \mathrm{clo})$, to represent a typical office conditions. The following individual differences in thermal comfort were also factored in the CFD design interface (i.e. using the $\mathrm{CFF}$ ):

- Age effects: non-significant

- Sex effects: non-significant

- Time of the day effects: non-significant

The PMV thermal sensation scale ranges from -3 to +3 and is defined as follows: +3 hot, +2 warm, +1 slightly warm, 0 neutral, -1 slightly cool, -2 cool and -3 cold (BS EN ISO 7730 2005) .

\section{Transport Phenomena}

The effects of air, $\mathrm{CO}_{2}$ and water vapour $\left(\mathrm{H}_{2} \mathrm{O}\right)$ transport were modelled by solving the conservation equations describing convection, diffusion, and reaction sources of each component (ANSYS 2014a).

Carbon dioxide $\left(\mathrm{CO}_{2}\right)$ was introduced as a mass fraction equating to an average external background concentration of $400 \mathrm{ppm}$. Introducing a mixture of water vapour with air in fluent for a given temperatures enabled the calculation of relative humidity (RH) as well as the effects of $\mathrm{H}_{2} \mathrm{O}$ and $\mathrm{CO}_{2}$. The moisture element modelled was considered to be generated from the number of people in the building (Table 2). In the transport phenomena, $\mathrm{RH}$ is the ratio of the partial pressure of the water vapour actually present in an air-water mixture to the saturation pressure of water vapour at the mixture temperature. To simulate the saturation pressure $\left(P_{s}\right)$ Equation 11 and 12 were used. where

$P_{C}=22.089 \mathrm{MPa} ; T_{C}=647.286 \mathrm{~K} ; T_{P}=338.15 \mathrm{~K} ; F_{l}$ $=-7.4192420 ; F_{2}=2.9721000 \times 10^{-1} ; F_{3}=-1.1552860$ $\times 10^{-1} ; F_{4}=8.6856350 \times 10^{-3} ; F_{5}=1.0940980 \times 10^{-3} ;$ $F_{6}=-4.3999300 \times 10^{-3} ; F_{7}=2.5206580 \times 10^{-3} ; F_{8}=$ $5.2186840 \times 10^{-4} ; a=0.01$ (ANSYS 2014b)

At a known working external temperature $T$ (see Table 2 ), the saturated pressure, $P_{s}$, is computed from Equations 11 and 12. Knowing $P_{s}$ the other parameters are computed to obtain the mass fraction of air and water vapour assuming a known mass fraction of $\mathrm{CO}_{2}$. The saturated mass fraction $\left(M f_{S}\right)$ at $1 \mathrm{~atm}$ of air and water $\left(\mathrm{H}_{2} \mathrm{O}\right)$ is computed using the relations in Equation 13-16, where $m_{w}$ is the molecular weight of the substance.

$M f_{S}=\frac{P_{s}(\text { bar }) \times m_{w} \text { of } \mathrm{H}_{2} \mathrm{O}}{\left\{\left[P_{s}(\text { bar }) \times m_{w} \text { of } \mathrm{H}_{2} \mathrm{O}\right]+\left[1 \text { bar }-P_{s}(\text { bar })\right] \times m_{w} \text { of air }\right\}}$

The saturated $\mathrm{kg}$ of $\mathrm{H}_{2} \mathrm{O}$ per kg of dry air $\left(\mathrm{sH}_{2} \mathrm{O}\right)$

$\mathrm{sH}_{2} \mathrm{O}=\mathrm{Mf} /\left(1-\mathrm{Mf}_{S}\right)$

Mf of $\mathrm{H}_{2} \mathrm{O}=1-\left[(\right.$ External $\left.\mathrm{RH}(\%) / 100(\%)) \times M f_{S}\right]$

Mf of Air $=1-\mathrm{Mf}$ of $\mathrm{H}_{2} \mathrm{O}$

These mass fractions $(M f)$ were then introduced into the transport phenomena in the CFF fluent interface which is then simulated.

\section{Numerical Analysis}

The scenarios considered for each set-up were for the cases outlined in Table 2. The key analysis that is drawn into graphical representations is developed for analysis using contours and streamlines. This was standardised for all three modelling strategies to enable effective comparison of simulated outputs. However, additional variations are considered during the analysis of the SVB design which forms the main investigation of this study. All flow patterns were influenced by the internal partitioning of the design cases.

$$
\begin{aligned}
& \ln \frac{P_{S}}{P_{C}}=\left(\left(T_{c} / T\right)-1\right) \times \sum_{i=1}^{8} F_{i}\left[a\left(T-T_{P}\right)\right]^{i-1} \\
& P_{S}(M P a)=P_{C} \operatorname{Exp}\left\{\left(\left(T_{c} / T\right)-1\right) \times \sum_{i=1}^{8} F_{i}\left[a\left(T-T_{P}\right)\right]^{i=1}\right\}
\end{aligned}
$$




\subsection{Results}

Air velocities were introduced into the three design cases via the ventilation inlets at the side and the back of the building. In Case 3, there were additional flows introduced through the inlet vents along the stack. The air flow stratification shows recirculation around the zones and volumes forming a continuous loop. The streamlines from the inlet in Figure 7 shows a very controlled path for the flow of fresh air.

\section{Velocities}

The predicted streamline profile in cases 1 and 2 illustrates very low flow velocities and a sudden decrease meters away from the inlet source, indicating a convective loss. From these streamline flows and resulting air movements it is obvious that fans would be required to ensure adequate movement of air through the buildings. Figure 8 shows the wind speeds from the inlet was high (between $2.2-3.1 \mathrm{~m} / \mathrm{s}$ ) because of the linear arrangements of zones from one floor to the next. This eventually reducing to very low speeds $(\sim 0$ $\mathrm{m} / \mathrm{s}$ ), away from the source. However towards the outlet the flow velocities increase $(0.9-1.3 \mathrm{~m} / \mathrm{s})$ again but less than what was introduced at the inlet. As would be expected, the velocity intensity in Figure 9 flows similar patterns. However the flow patterns experience high velocities $(0.8-1.3 \mathrm{~m} / \mathrm{s})$ within the building because of the open plan design configuration due to less zonal partitioning. The airflows again in a linear arrangement (i.e. in the direction of the arrow-inset) with air velocities increasing to about $1.8 \mathrm{~m} / \mathrm{s}$ at the outlet.

In Case 3, with this design configuration; inlets at the side (lower floor) and from the rear end (Figure 10), the flow patterns illustrates linear and turbulent flow patterns .Significantly, the difference in the density of the warmer indoor air and cool external air, creates the difference in pressure that allows the constant movement of air. This is illustrated by the streamlines in Figure 10. In this instance convective ventilation is said to be applicable since this is based on the principles that cool air replaces hot air that rises and exits at the top of the building. Cool air enters from lower levels (at the inlets). It must be noted that, the convective flows that results in stack effects, works best if the inlet air supply is at a significantly lower level possible. Consequently where there are designed stacks for air movement, the stack effect is more noticeable with high flows along the stack towards the canopy (Figure 7) as illustrated by the arrow inset. This phenomenon is supported by arguments made by Binggeli (2010), where stack effect is more noticeable when buildings are constructed with four or more floors.

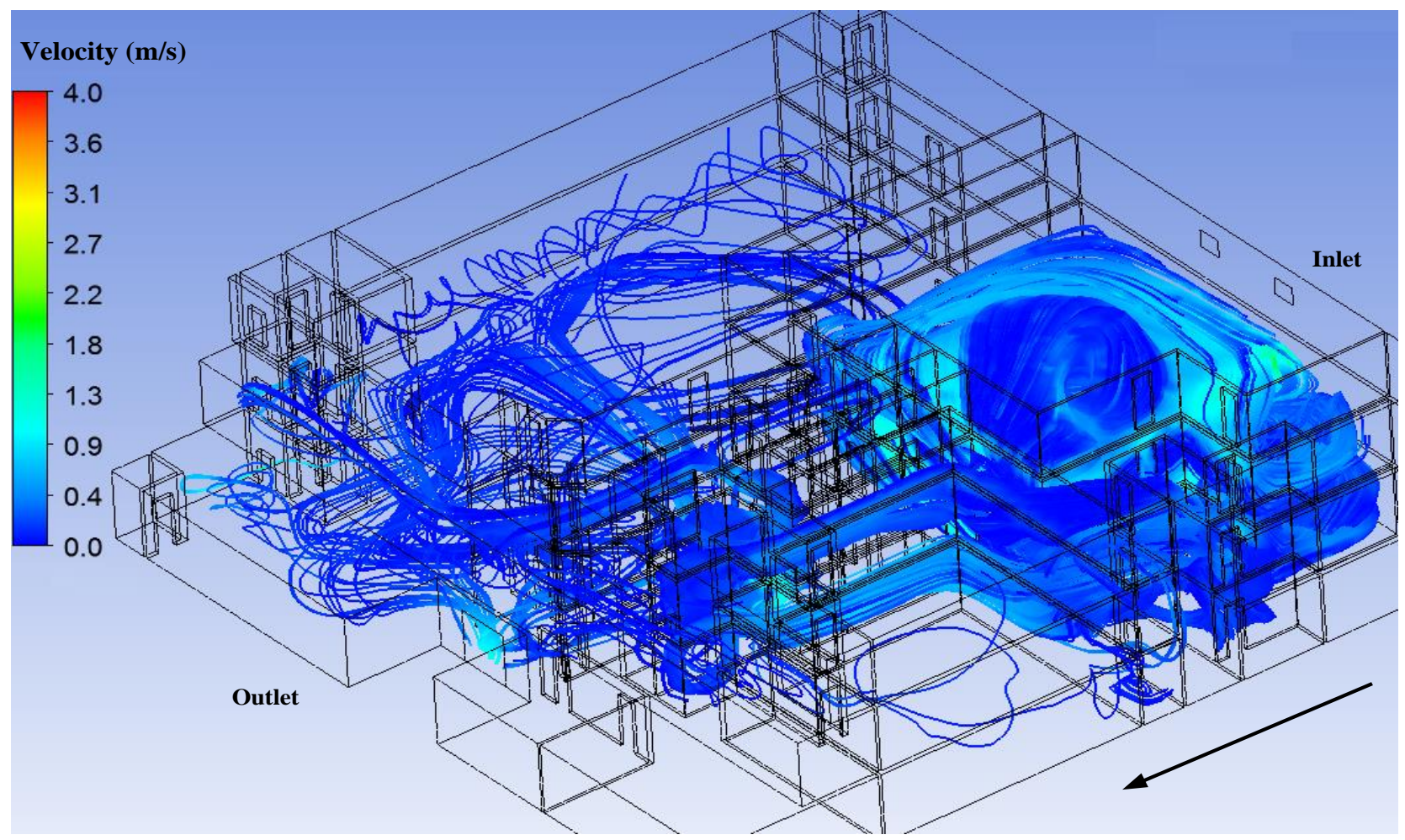

Figure 8. Velocity streamlines of Case 1, demonstrating air velocity in and around all the inner volumes with flow patterns from the inlet through to the outlet in the direction of the arrow (inset) 
The average air velocities (Tables 4 and 5) within the zones of this design were estimated to be between $0.67-1.81 \mathrm{~m} / \mathrm{s}$ in transition season $\mathrm{A}$ and $0.76-1.65 \mathrm{~m} / \mathrm{s}$ in transition season B. Details of the predicted ventilation rates and air changes per hour (ach) of the three Cases are also summarised in the tables.
Significantly, the supply stratification in Case 3 enhanced by the exhaust vents has the highest air change rates. This is relevant for climates such as that of Beijing (Chen, 2007), demonstrating that the general concept of this particular design works and it is functional for the operation of the design building.

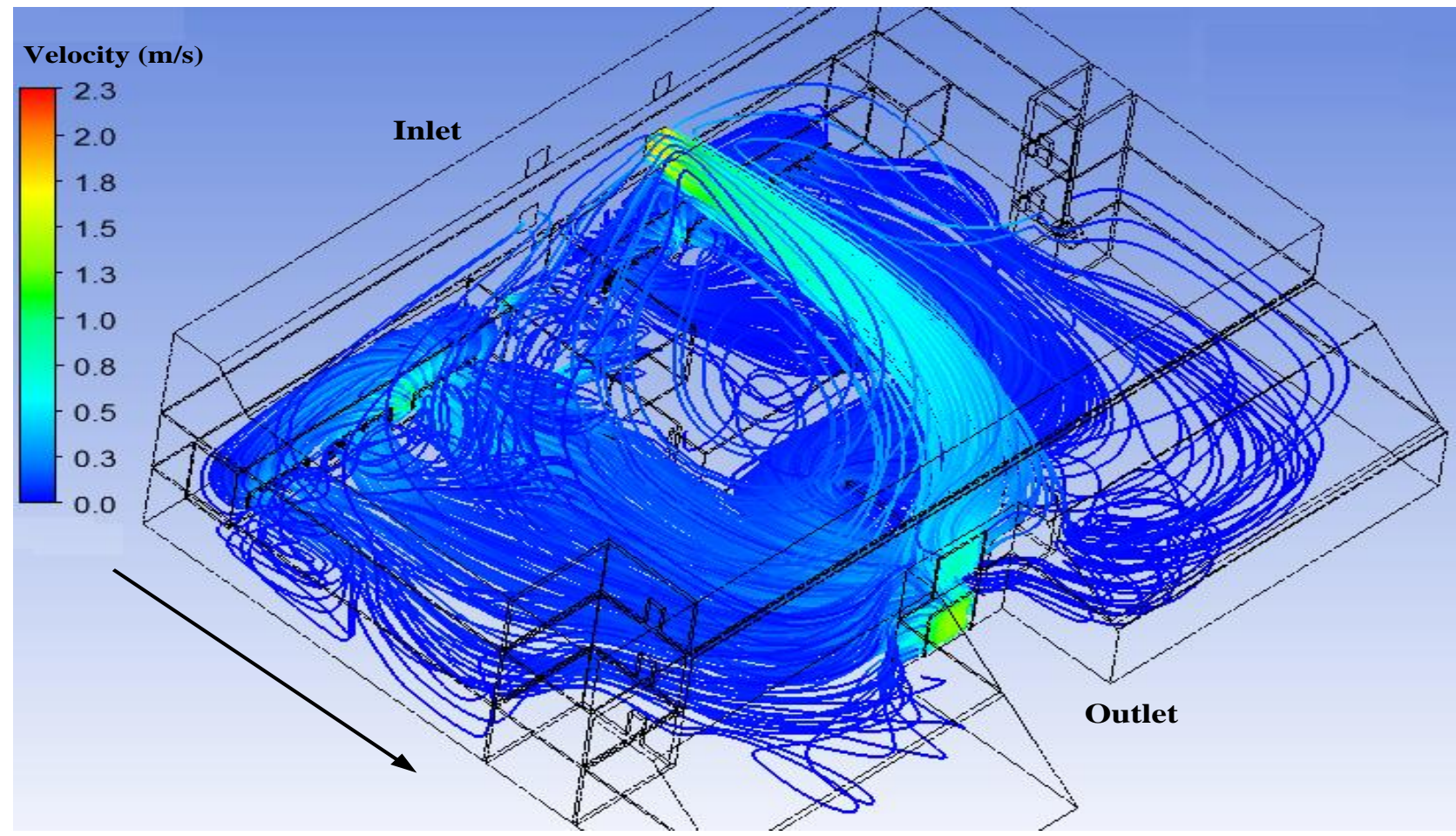

Figure 9. The airflow distribution of Case 2, around the inner volumes with flow patterns from the inlet through to the outlet in the direction of the arrow (inset.)

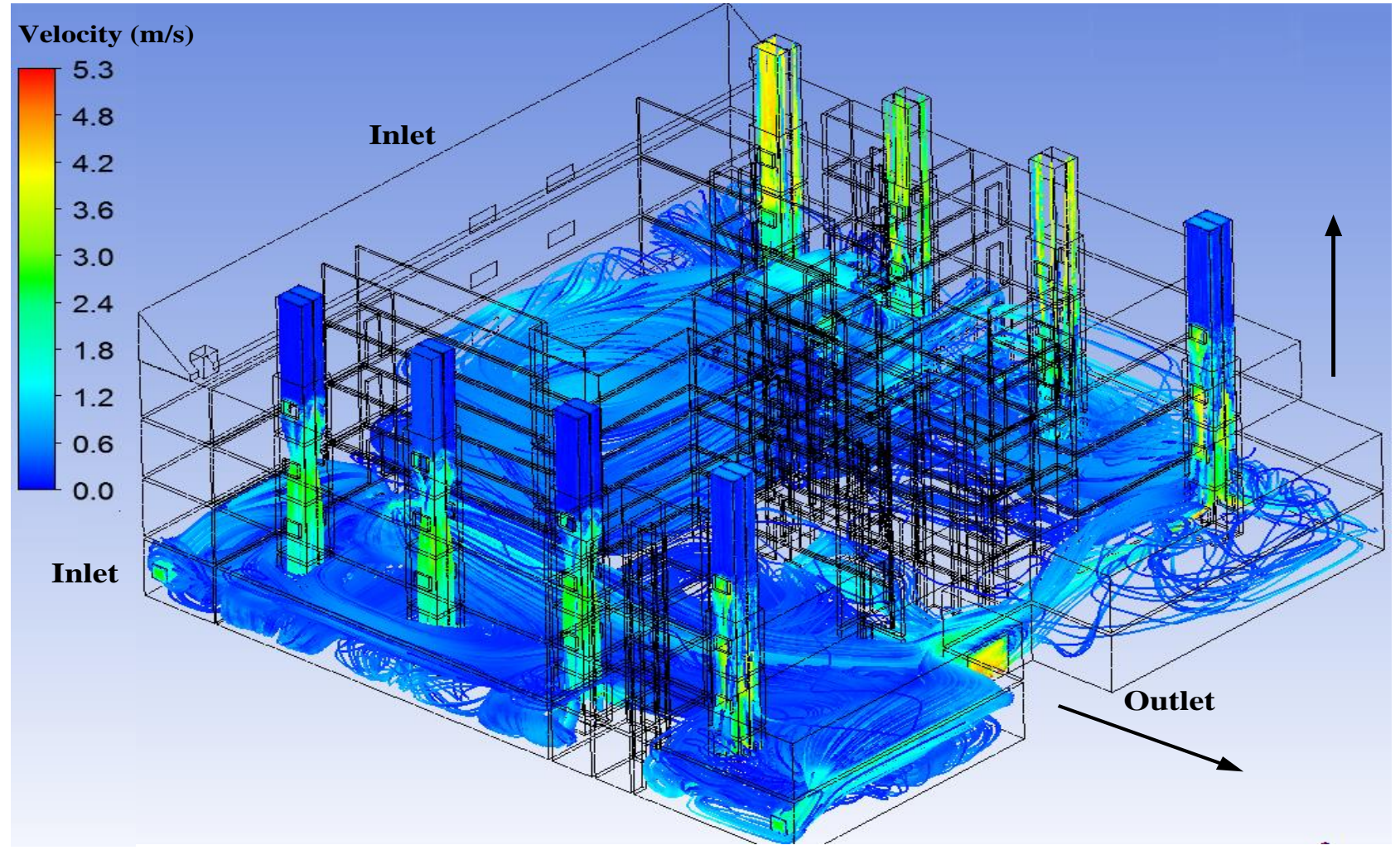

Figure 10. The airflow distribution of Case 3, around the inner volumes with flow patterns from the inlet through the 8 stacks and the outlet illustrated in the direction of the arrows (inset). 
Table 4. Parametric values inside the building estimated for Transition Period A

\begin{tabular}{|l|r|r|r|r|r|r|}
\hline \multirow{2}{*}{ CASES } & \multicolumn{2}{|c|}{ Case 1 } & \multicolumn{2}{c|}{ Case 2 } & \multicolumn{2}{c|}{ Case 3 } \\
\cline { 2 - 7 } PARAMETERS & Scenario 1 & Scenario 2 & Scenario 1 & Scenario 2 & Scenario 1 & Scenario 2 \\
\hline Velocity (m/s) & 0.67 & 1.04 & 1.03 & 1.10 & 1.62 & 1.81 \\
\hline Ventilation rate (1/s) & 10.1 & 27.7 & 18.2 & 28.0 & 34.7 & 38.8 \\
\hline Air change per hour (ach) & 0.41 & 1.13 & 0.64 & 0.99 & 2.44 & 2.72 \\
\hline
\end{tabular}

Table 5. Parametric values inside the building estimated for Transition Period B

\begin{tabular}{|l|r|r|r|r|r|r|}
\hline \multirow{2}{*}{ CASES } & \multicolumn{2}{|c|}{ Case 1 } & \multicolumn{2}{c|}{ Case 2 } & \multicolumn{2}{c|}{ Case 3 } \\
\cline { 2 - 7 } PARAMETERS & Scenario 1 & Scenario 2 & Scenario 1 & Scenario 2 & Scenario 1 & Scenario 2 \\
\hline Velocity (m/s) & 0.76 & 0.82 & 0.96 & 1.00 & 1.10 & 1.65 \\
\hline Ventilation rate (1/s) & 7.2 & 22.9 & 13.8 & 27.0 & 34.4 & 36.4 \\
\hline Air change per hour (ach) & 0.29 & 0.93 & 0.49 & 0.95 & 2.42 & 2.56 \\
\hline
\end{tabular}

\section{Estimation of thermal comfort parameters}

In this aspect of the study the PMV, PPD, temperature and concentration of $\mathrm{CO}_{2}$ investigated are discussed. The average values of the parameters were considered for each floor. All parameters were measured vertically in three heights relating to occupants standing, sitting and their ankle height (Mahyuddin and Awbi 2010; ISO 7726, 1998). The corresponding heights taken into account from the standing position were $1.8 \mathrm{~m}, 1.2 \mathrm{~m}$ and $0.1 \mathrm{~m}$ respectively.
These heights were maintained along the length of the building, considering their representative planes; at the front $\left(\mathrm{P}_{1}\right)$, middle $\left(\mathrm{P}_{2}\right)$ and close to the back wall $\left(\mathrm{P}_{3}\right)$, as illustrated in Figure 11. This is representative for each case. The values at convergence for the steady state simulation were then measured. PMV contours (i.e. selected from scenario 2, transition season B) shown in Figure 12 gives a good indication of the robustness of the thermal assessment code used. Similar contours were observed for PPD indicators. Comparing the three design cases, a good benchmark in which to judge the case studies is obtained. This is used to further evaluate the thermal assessment framework.

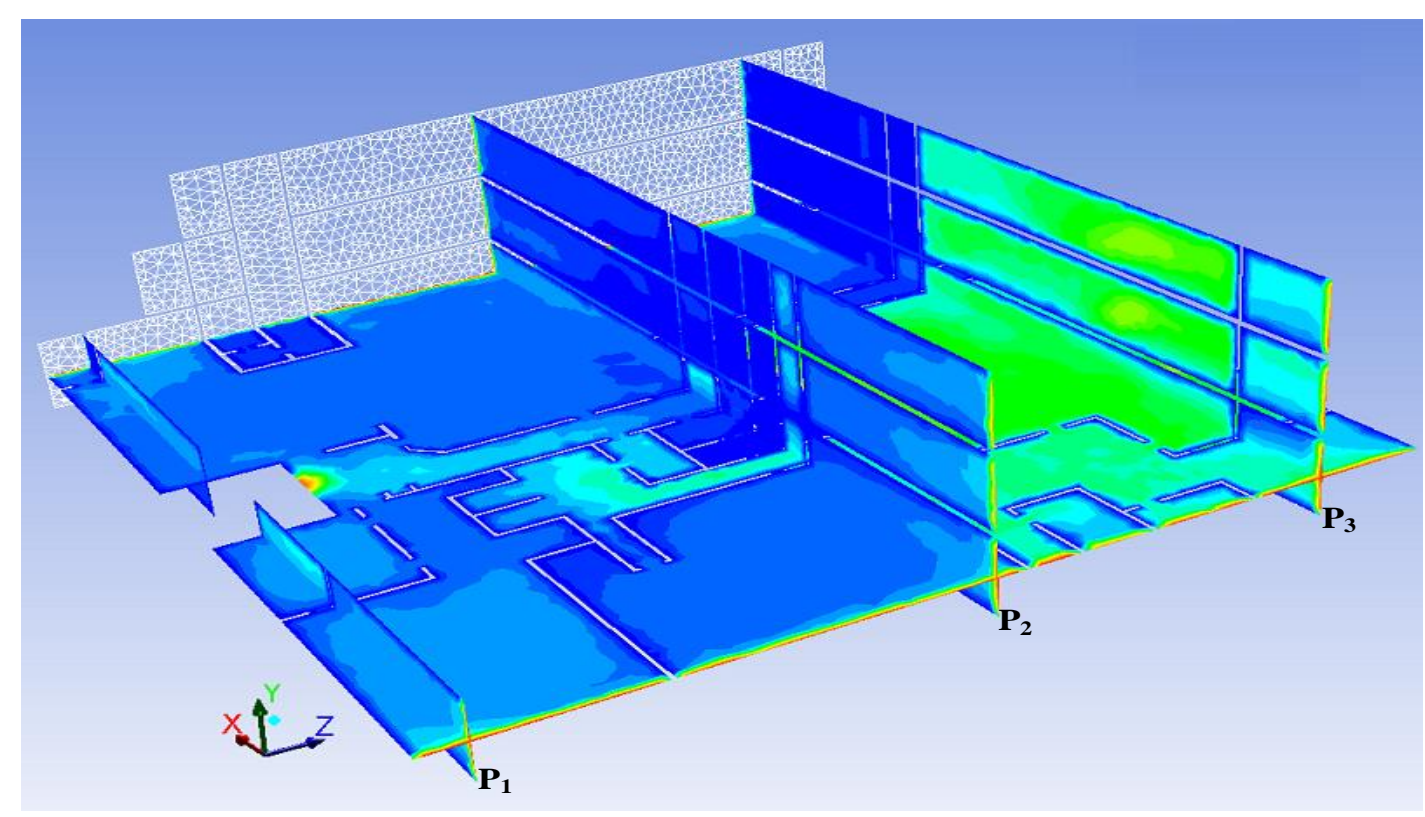

Figure 11. Typical representative planes extrapolated from the CFD simulations of each Case 


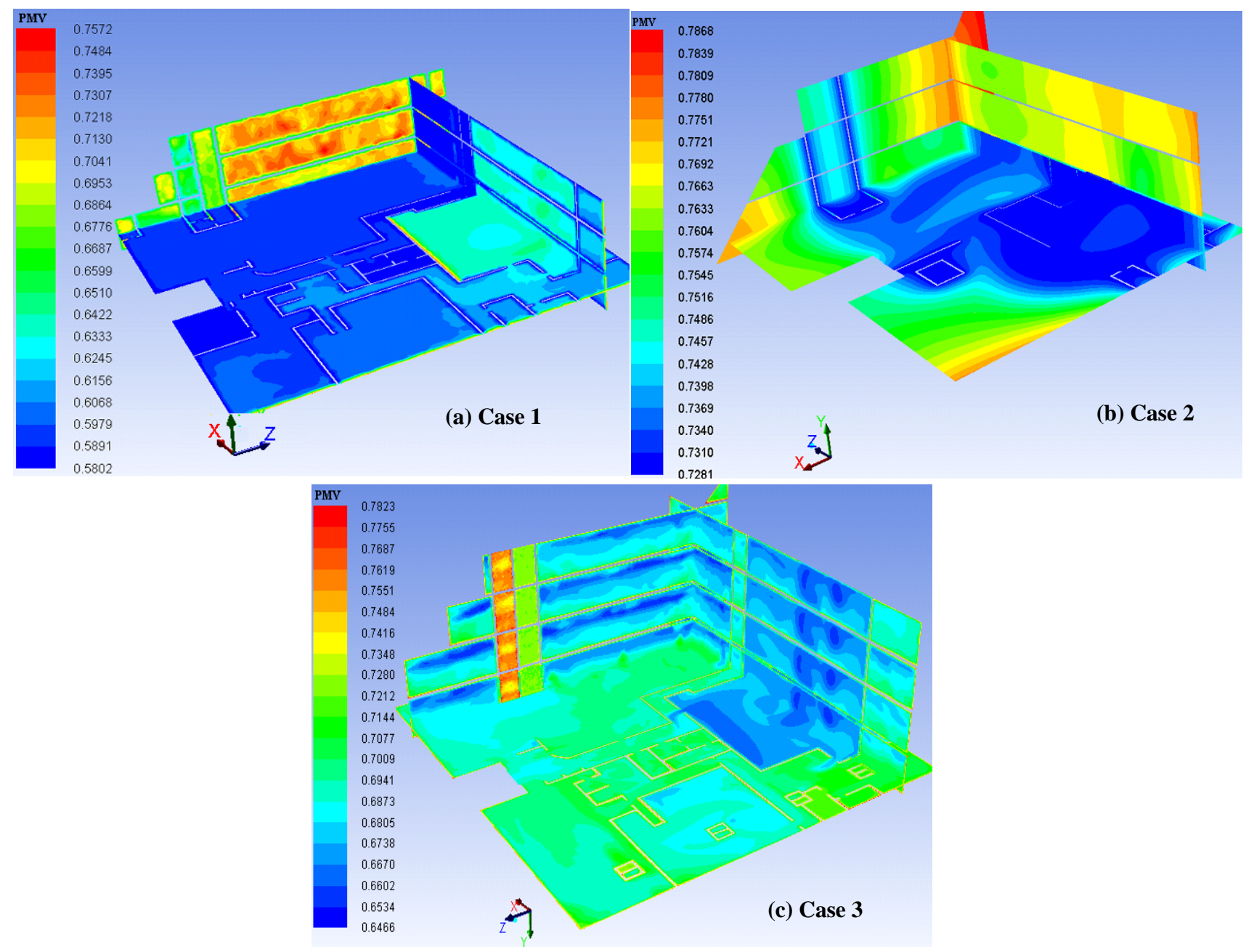

Figure 12. Simulated PMV contour plots in three surfaces (one horizontal and two vertical) in (a) Case 1, (b) Case 2, (c) Case 3

The values of PMV-PPD were computed using the above considerations. The values of PMV calculated from the simulated planes (Figure 11) at different indoor sections of the building design cases are presented in Tables 6 - 8. The values of indoor PMV in the tables are the average values of their defined planes along the stipulated heights. This is relevant for a better comparison between transition periods. It is observed that all sections in the three cases do not have suitable thermal comfort conditions in either transition periods (i.e. A and B). This is because their PMV indices do not fall within the range $(-0.5<\mathrm{PMV}<0.5)$. However, comparatively, design Case 1 demonstrates better thermal comfort conditions for all scenarios while Case 2 demonstrates the worse. From the figures presented, on average the thermal conditions (PMV values) in the middle of each building shows slightly better satisfaction than those at the front and close to the back wall. This may be attributed to a well-mixed stratification of airflows in the middle zone.
In addition, presented in Tables 6 - 8 is the summary of the analyses and results of the spatial distribution of average $\mathrm{CO}_{2}$ concentrations. Based on the analyses, the lowest average $\mathrm{CO}_{2}$ concentration was found in Case 3 . It was also observed that on average, the highest $\mathrm{CO}_{2}$ concentration was noticed in design Case 2 for each scenario.

In all scenarios analysed, the PPD values were more than $10 \%$, supporting the fact that the percentage of possible occupant dissatisfaction would be more than the ideal case of $10 \%$. Significantly, four results were also deduced. First, though from the tables 6-8 the recommended PPD values were not achieved, values obtained in Case 1 were the closest to the required range. The second observation was that the PPD values from Case 2 were slightly higher than in Cases 1 and 3. 
Table 6. Comparison of various thermal comfort parameters for design Case 1

\begin{tabular}{|c|c|c|c|c|c|}
\hline \multirow[t]{2}{*}{ PARAMETERS } & \multicolumn{2}{|c|}{ Transition Period A } & \multicolumn{2}{|c|}{ Transition Period B } & \multirow[t]{2}{*}{ Ideal } \\
\hline & Scenario 1 & Scenario 2 & Scenario 1 & Scenario 2 & \\
\hline $\begin{array}{l}\mathbf{P M V} \\
\quad \text { *Back }\left(\mathbf{P}_{1}\right) \\
\quad \text { *Middle }\left(\mathbf{P}_{2}\right) \\
\quad \text { *Front }\left(\mathbf{P}_{3}\right)\end{array}$ & $\begin{array}{l}0.68 \pm 0.02 \\
0.57 \pm 0.01 \\
0.61 \pm 0.02\end{array}$ & $\begin{array}{l}0.63 \pm 0.02 \\
0.58 \pm 0.02 \\
0.59 \pm 0.02\end{array}$ & $\begin{array}{l}0.67 \pm 0.03 \\
0.57 \pm 0.02 \\
0.62 \pm 0.02\end{array}$ & $\begin{array}{l}0.62 \pm 0.02 \\
0.57 \pm 0.02 \\
0.58 \pm 0.02\end{array}$ & $-0.5<\mathrm{PMV}<0.5$ \\
\hline $\begin{array}{l}\mathbf{P P D} \\
\quad \text { *Back }\left(\mathbf{P}_{1}\right) \\
\quad * \text { Middle }\left(\mathbf{P}_{2}\right) \\
\quad \text { *Front }\left(\mathbf{P}_{\mathbf{3}}\right)\end{array}$ & $\begin{array}{l}15.5 \\
12.0 \\
12.3\end{array}$ & $\begin{array}{l}13.6 \\
12.1 \\
12.1\end{array}$ & $\begin{array}{l}14.0 \\
12.0 \\
12.9\end{array}$ & $\begin{array}{l}13.3 \\
12.0 \\
12.1\end{array}$ & $\leq 10$ \\
\hline Temperature $\left({ }^{\circ} \mathbf{C}\right)$ & $21-23$ & $20-23$ & $19-21$ & $20-21$ & - \\
\hline Humidity (\%) & $20-52$ & $11-56$ & $15-66$ & $14-35$ & $40-70$ \\
\hline $\mathrm{CO}_{2}(\mathrm{ppm})$ & $4000-12000$ & $4000-12000$ & $4000-14000$ & $2000-4000$ & - \\
\hline
\end{tabular}

*P1 to P3 are the cross section of the plans illustrated in Figure 11

Table 7. Comparison of various thermal comfort parameters for design Case 2

\begin{tabular}{|c|c|c|c|c|c|}
\hline \multirow[t]{2}{*}{ PARAMETERS } & \multicolumn{2}{|c|}{ Transition Period A } & \multicolumn{2}{|c|}{ Transition Period B } & \multirow[t]{2}{*}{ Ideal } \\
\hline & Scenario 1 & Scenario 2 & Scenario 1 & Scenario 2 & \\
\hline $\begin{array}{l}\mathbf{P M V} \\
\quad \text { *Back }\left(\mathbf{P}_{1}\right) \\
\quad \text { *Middle }\left(\mathbf{P}_{2}\right) \\
\quad \text { *Front }\left(\mathbf{P}_{\mathbf{3}}\right)\end{array}$ & $\begin{array}{l}0.76 \pm 0.02 \\
0.73 \pm 0.02 \\
0.76 \pm 0.02\end{array}$ & $\begin{array}{l}0.72 \pm 0.01 \\
0.71 \pm 0.01 \\
0.65 \pm 0.01\end{array}$ & $\begin{array}{l}0.76 \pm 0.01 \\
0.73 \pm 0.03 \\
0.76 \pm 0.01\end{array}$ & $\begin{array}{l}0.72 \pm 0.01 \\
0.71 \pm 0.01 \\
0.65 \pm 0.02\end{array}$ & $-0.5<\mathrm{PMV}<0.5$ \\
\hline $\begin{array}{l}\text { PPD } \\
\quad \text { *Back }\left(\mathbf{P}_{1}\right) \\
\quad \text { *Middle }\left(\mathbf{P}_{2}\right) \\
\quad \text { *Front }\left(\mathbf{P}_{3}\right) \\
\end{array}$ & $\begin{array}{l}17.3 \\
16.3 \\
17.2 \\
\end{array}$ & $\begin{array}{l}16.1 \\
15.2 \\
14.1\end{array}$ & $\begin{array}{l}17.3 \\
16.2 \\
17.2\end{array}$ & $\begin{array}{l}16.0 \\
15.5 \\
14.0\end{array}$ & $\leq 10$ \\
\hline Temperature $\left({ }^{\circ} \mathbf{C}\right)$ & $19-25$ & $19-22$ & $19-25$ & $20-23$ & - \\
\hline Humidity (\%) & $10-44$ & $14-43$ & $11-44$ & $30-52$ & $40-70$ \\
\hline $\mathrm{CO}_{2}(\mathrm{ppm})$ & $2200-28000$ & $2200-32000$ & $2400-32000$ & $2240-24000$ & - \\
\hline
\end{tabular}

* P1 to P3 are the cross section of the plans illustrated in Figure 11

Table 8. Comparison of various thermal comfort parameters for design Case 3

\begin{tabular}{|c|c|c|c|c|c|}
\hline \multirow[t]{2}{*}{ PARAMETERS } & \multicolumn{2}{|c|}{ Transition Period A } & \multicolumn{2}{|c|}{ Transition Period B } & \multirow[t]{2}{*}{ Ideal } \\
\hline & Scenario 1 & Scenario 2 & Scenario 1 & Scenario 2 & \\
\hline $\begin{array}{l}\mathbf{P M V} \\
\quad \text { *Back }\left(\mathbf{P}_{1}\right) \\
\quad \text { *Middle }\left(\mathbf{P}_{2}\right) \\
\quad \text { *Front }\left(\mathbf{P}_{\mathbf{3}}\right)\end{array}$ & $\begin{array}{l}0.76 \pm 0.01 \\
0.71 \pm 0.01 \\
0.75 \pm 0.01\end{array}$ & $\begin{array}{l}0.68 \pm 0.02 \\
0.67 \pm 0.02 \\
0.65 \pm 0.02\end{array}$ & $\begin{array}{l}0.74 \pm 0.01 \\
0.72 \pm 0.02 \\
0.74 \pm 0.02\end{array}$ & $\begin{array}{l}0.66 \pm 0.01 \\
0.68 \pm 0.01 \\
0.67 \pm 0.01\end{array}$ & $-0.5<\mathrm{PMV}<0.5$ \\
\hline $\begin{array}{l}\text { PPD } \\
\quad \text { *Back }\left(\mathbf{P}_{1}\right) \\
\quad \text { *Middle }\left(\mathbf{P}_{2}\right) \\
\quad \text { *Front }\left(\mathbf{P}_{\mathbf{3}}\right) \\
\end{array}$ & $\begin{array}{l}17.3 \\
15.5 \\
16.8\end{array}$ & $\begin{array}{l}14.9 \\
14.6 \\
14.1\end{array}$ & $\begin{array}{l}16.9 \\
16.0 \\
16.8\end{array}$ & $\begin{array}{l}14.3 \\
14.8 \\
14.6\end{array}$ & $\leq 10$ \\
\hline Temperature $\left({ }^{\circ} \mathrm{C}\right)$ & $19-23$ & $18-23$ & $20-24$ & $20-23$ & - \\
\hline Humidity (\%) & $46-55$ & $34-40$ & $27-39$ & $26-35$ & $40-70$ \\
\hline $\mathrm{CO}_{2}(\mathrm{ppm})$ & $2000-4000$ & $2400-4360$ & $2000-6000$ & $400-4360$ & - \\
\hline
\end{tabular}

*P1 to P3 are the cross section of the plans illustrated in Figure 11

This is due to the effect of the integrated glazing within façade of the building, as well as the climate of Beijing. Thirdly, external conditions with higher outdoor temperatures (Table 3) as shown in scenarios 1 of both transition periods is noticed to have the highest PMV and PPD values. This could be inferred to mean that occupants will have more discomfort in warm conditions than the cool conditions. Finally, the comparison of PPDs in identical scenarios shows that on average there were no significant differences between PPD values in transition periods A or B. 


\section{Conclusions}

The impact and attributes of natural ventilation in three different building designs have been investigated using CFD simulations. This paper presents generic predictions, discussing the significance of incorporating stack ventilation interventions into a building in Beijing. The three design cases represent different building configurations; each investigated for conditions in the transition periods (Figure 6) of Beijing, China.

The results obtained from the simulations predicted how buoyancy driven ventilation system would naturally provide greater ventilation to more spaces that are sparsely and/or densely occupied. This is evident in Case 3 which shows between $10-50 \%$ reduction of possible indoor air pollutants (in the form of $\mathrm{CO}_{2}$ and $\mathrm{H}_{2} \mathrm{O}$ vapour concentrations). It was predicted in Cases 1 and 2 that these building types cannot depend on convective forces alone to improve the uptake for natural ventilation; as a result fans would be required to achieve acceptable air movement within the buildings. The simulation results establish that Case 2 which has a fully glazed facade is the least suitable for the continental climate experienced in Beijing. This is due to relatively low air movements within the internal zones.

The research findings presented in this paper illustrates, using key examples how architects can work with engineers to design a sustainable building - taking into consideration the initial design from an "as built" through the evaluation of two possible architectural designs, using engineering techniques to ensure that the architects design is well investigated to obtain detailed flow information before it is built. The lessons that can be learnt from investigating an architects design using engineering techniques is notable in the sense that, it demonstrates that using CFD detailed airflow information about the proposed building types is understood and its significance on comfort is also echoed.

The numerical results obtained from all three Cases are acceptable and aligned with ISO 7730 (2005) recommendations for thermal comfort. Higher levels of PMV, PPD and $\mathrm{CO}_{2}$ concentrations were recorded for design Case 2. The simulation illustrates using a SVB (Case 3) improves the comfort and a healthy indoor environmental. Nevertheless, comparatively the indoor environment of Case 1 showed better thermal conditions.
Considering the fact that the same boundary conditions were applied to all three design cases, the values discussed reflects simulation patterns that would be expected within these building interventions. However, the values presented in this paper should be considered within the specifications of the boundary conditions.

\section{Acknowledgment}

The authors would like to thank the financial support from the Visiting Fellow Grant funded by the Key Laboratory of the Three Gorges Reservoir Region's Eco-Environment, Ministry of Education at Chongqing University, China.

\section{References}

Abanto, J., Barrero, D., Reggio, M. and Ozella, B. 2004 Air flow modelling in a computer room. Building and Environment 39, pp $1393-1402$

Ansys Fluent, 2014a, Release 15 User GuideChapter 16: Modelling Species Transport and Finite-Rate Chemistry

Ansys Fluent,. 2014b. Release 15 Help files. Alphabetical Listing of Field Variables and Their Definitions, section 34.4

ASHRAE, 2009_Handbook Fundamentals SI Edition, ISBN 978-1-933742-55-7, pp 172

Awbi, H.B. 1998 Calculation of convective heat transfer coefficients of room surfaces for natural convection. Energy and Buildings, 28, $219-227$

Binggeli, C. 2010 Building systems for interior designers - 2nd Edition. Published by John Wiley \& sons Inc, USA. Pp 179. ISBN 978-0-470-22847-0

Blocken, B., Staf, R. and Carmeliet, J. 2005 A Combined CFD-HAM approach for wind-driven rain on building facades. Journal of Wind Engineering and Industrial Aerodynamics, Volume 9 (7), pp. 585-607

BS EN ISO 7730. 2005. Ergonomics of the thermal environment-Analytical determination and interpretation of thermal comfort using calculation of the PMV and PPD indices and local thermal comfort criteria

Chen, Q. 2007. Design of natural ventilation with CFD (Chapter 7). In Sustainable Urban Housing in China: principles and case studies for low-energy design. 
Editors: Glicksman, Leon, Lin, Juintow (Eds.). Pp 116-122

Chow, W.K. 1996 Application of Computational Fluid Dynamics in building services Engineering. Building and Environment, 31 (5), pp. 425-436

CSWD, 2005 "China Standard Weather Data for Building Thermal Environment Design", China Meteorological Administration and Tsinghua University, China Architecture and Building Press, ISBN 7-112-07274-3. [in Chinese]

Essah E.A. 2009 Modelling and measurements of airflow and ventilation within domestic pitched roofs". $\mathrm{PhD}$ Thesis. Glasgow Caledonian University, Glasgow, UK

Fanger, P.O.1972 Thermal Comfort: Analysis and applications in environmental engineering, McGraw-Hill, New York

Gaspar, P.D., Barroca, F. R. and Pitarma, R.A. 2003 Performance Evaluation of CFD codes in building energy and environmental analysis. International Building Simulation Conference (IBPSA), Eindhoven,-Netherlands. pp. 371-378

ISO 77261998 Ergonomics of the thermal environment -- Instruments for measuring physical quantities

Jankovic, L. 2012 Designing Zero Carbon Buildings-using dynamic simulation methods. $1^{\text {st }}$ Edition, Taylor \& Francis publishers, ISBN: 978-184971-294-1,pp120-122

Ji Y., Lomas K. J. and Cook M J. 2009. Hybrid ventilation for low energy building design in south China. Building and Environment. Building and environment, 44 (11), pp. 2245-2255.

Kennett S. 2001 Model Answer, Building Services Journal, Vol. 23, No. 9, the Chartered Institution of Building Services Engineers, pp. 42-43, UK

Kim, M. and Hwang, J. 2009. Performance prediction of a hybrid ventilation system in an apartment house. Energy and buildings, 41(6), pp.579-586

Liddament, M.W. 1996. A Guide to Energy Efficiency Ventilation- AIVC Guide to Ventilation. Annex V, Coventry, UK. pp 11, 15, 19-20
Li, K. and Li, X. 2013. Simulation study on natural ventilation in Beijing: the influence of room structure on energy saving. Proceedings in the $13^{\text {th }}$ international conference of Building Performance Simulation Association. France, August 26-28

Lomas K. J. 2007. Architectural design of an advanced naturally ventilated building form. Energy and buildings, 39, pp.166-181

Loomans, M.G.L.C.1998 The measurement and simulation of indoor airflow-PhD Thesis- Technical University, Eindhoven, ISBN 90-6814-085-X, pp. 1-6, 29

Mahyuddin, N, Awbi, H. and Essah, E.A, 2014.

Computational fluid dynamics modelling of the air movement in an environmental test chamber with a respiring manikin. Journal of Building Performance Simulation, DOI: 10.1080/19401493.2014.956672

Mahyuddin, N and Awbi, H., 2010. The spatial distribution of carbon dioxide in an environmental test chamber. Building and Environment 45 pp. 1993- 2001

Nielsen, P.V., Allard, F., Awbi, H. B., Davidson, L. and Schälin, A. 2007 Computational Fluid Dynamics in Ventilation Design -Guide Book No.10. pp. 27, REHVA, ISBN 2-9600468-907

Short, A.C., Yao, R., Luo, G. and Li, B. 2012 Exploiting a hybrid environmental design strategy in the continental climate of Beijing. International Journal of Ventilation, 11(2), pp105-130

Short, C.A and Lomas, K.J. 2007 Exploiting a hybrid environmental design stratergy in a US continental climate. Building Research \& Information,35(2), pp $119-143$

Yao, R., Li, B., Steemers, K. and Short, A. 2009 Assessing the natural ventilation cooling potential of office buildings in different climate zones in China. Renewable energy, 34(12), pp.2697-2705.

Zhai, Z. J., Johnson, M. and Krarti, M. 2011 Assessment of natural and hybrid ventilation models in whole-building energy simulations. Energy and buildings, 43(9), pp. 2251-2261. 